\title{
4. The Voter Education Program: Growing a Demand for Good Governance
}

\author{
Susan Ferguson ${ }^{1}$
}

\section{Introduction}

Participation in voter education changed the lives of many people who ran voter awareness projects for the 2007 general elections in Papua New Guinea. It changed the voting behaviour of a proportion of those who took part in the program. This account of the voter education program through civil society organizations (CSOs) is a personal account from a participant in the process, since the key to electoral awareness lay in its participatory nature. My account is backed up by an evaluation of the program, but is essentially a subjective diary of what we did.

In March 2006 I was appointed as the communications adviser within the Electoral Support Program. The Electoral Support Program was, at the time, a three-year program funded by the Australian Agency for International Development (AusAID). The overall aim of the program was to support the Papua New Guinea Electoral Commission (PNGEC) run free and fair elections. I was specifically responsible for implementing a component of the program which aimed to improve awareness and understanding of the electoral system by voters and the community as a whole. Although my official role was capacity building within the PNGEC to run community awareness, the reality was that the program had a generous budget to fund CSOs to run voter education across the country. Inevitably I was drawn into running and managing an extensive grants program, which took me away from hands-on capacity building within the PNGEC itself. Since this grants program was not to be ongoing, nor considered core work of the PNGEC, there was no necessity to build the PNGEC's capacity to run such a program, yet there was a necessity under the design of the Electoral Support Program to deliver the grants to run voter education.

\footnotetext{
1 As coordinator of the voter education awareness program I worked closely with Esmie Sinapa, the Electoral Support Program activity manager, and Daisy Taylor, who was contracted to develop a range of electoral awareness materials. This paper draws on my experience working within the Information and Community Awareness Division of the Electoral Commission and on an evaluation of the voter education process led by Stephen Gari. Other members of the team included Michael Unage, Suzette Holm and Pastor Solomon Minga. I am grateful for the work they did and acknowledge their contribution to this story.
} 
Within the PNGEC, I worked alongside the director of the Information and Community Awareness Division to develop a communication strategy that guided the process of community awareness across the country. The strategy was called Election News! Election Sivarai! Eleksen Toksave! It included media awareness, development of electoral awareness materials, and the creation of partnerships within government and beyond, including the civil society aspect of the electoral awareness.

This paper provides an account of the communication strategy, concentrating on the innovative grants program - innovative because, for the first time since the early 1970s, the commission was involved in trying to grow a demand for better elections across the country, rather than simply providing information about the logistics of elections. It talks about what worked and what didn't work.

\section{Background}

It is well documented that Papua New Guinean elections suffer from a range of damaging voter behaviour entrenched within the public. This behaviour includes accepting bribes to vote for certain candidates, discarding the electoral roll in favour of 'line up' voting, voting more than once and in some cases many times, underage voting, and intimidation of voters by candidate supporters (especially intimidation of women, older people and illiterate voters). One aspect of behaviour which is damaging to the running of free and fair elections in the country is public collusion in the development of a fraudulent electoral roll. The basis of much of the illegal activity around elections is a fraudulent roll. For example, a vastly inflated roll means that certain wards will be allocated too many ballot papers; this allows for multiple voting.

Much of this behaviour cannot be controlled during elections by presiding officers at polling stations, or by police or the army. It is too widespread. Although there are quite tough penalties for some offences, such as six months imprisonment for putting a ballot paper not your own into a ballot box, they are rarely enforced due to the extent of the behaviour (in some parts of the country, it would be necessary to charge 90 percent of the voting population) and the general acceptance of such behaviour by the public.

A report commissioned by the Electoral Support Program to assess baseline voter education issues revealed that:

voters and candidates have their own picture about the purpose of elections, as well as the 'real rules' of how elections are actually carried out - this picture varies across the country in its compliance with formal 
rules and violence ... there is a widespread view that elections are there to be won, by whatever means. Voters do not understand and accept core standards of voting, fairness, tolerance, and the connection to the wider democratic system (Ladley and Williams 2007, quoted in Gari, Holm and Ferguson 2008:189).

The baseline study points out that research around the world suggests that the single most important factor in running viable elections that follow the official rules is voter compliance. Most voters must know the rules, accept the rules, and follow the rules in order for democratic elections to function. At least two things must be in place for this acceptance and compliance to occur. The first is knowledge of and agreement with the system: What is a democracy? Why do we have elections? What can we expect from leaders? What is the role of government? Why is our vote important? What is the purpose of actually voting? The second is faith in the system: If we follow the rules, will everyone else? Will our leaders represent us if we vote for them? Can we trust them?

The voter education program that we ran with CSOs attempted to increase knowledge and understanding of the democratic system and to begin to grow a demand for properly run elections that produced trustworthy candidates.

The baseline study also showed that the most effective voter education programs have three elements: general civics education that provides people with information about the broad democratic system; governance education that gives people information about how the government system runs; and electoral information that educates people about how to vote and what to expect during elections.

In the past, the PNGEC's communication strategies had only seriously addressed the third of these. The design of the Electoral Support Program allowed for the other two as well. The communication strategy that the PNGEC agreed to reflected all three elements of voter education.

There were three outcome areas within the communication strategy, Election News! Election Sivarai! Eleksen Toksave! The first was to improve awareness about the recently introduced limited preferential voting (LPV) system and the electoral process in the community. The aim of this was to enable free and fair elections through increased understanding of the electoral system and equal public participation. The second was to strengthen partnerships with stakeholders to deliver to the community awareness of LPV and the electoral process. The aim of the third was to design materials with strategic partners that had specific messages for different groups, recognizing the diversity within Papua New Guinea. 
The agreed principles of the strategy were:

- elections are everybody's business, so the Electoral Commission will need to work with everybody to get the messages out

- messages need to be clear and effective

- all messages will be politically neutral

- coordination across different groups with an interest in elections will make the communication strategy more effective

- Papua New Guinea is very diverse so there will need to be many different ways of getting the messages to different groups - one size does not fit all.

The PNGEC's communication strategy was the backbone of the civil society awareness work. Every two or three months, a communication advisory committee, chaired by the director of Information and Community Awareness Division within the commission, met to overview the communication strategy, with particular emphasis on civil society awareness. In this way, civil society awareness was very much a part of the PNGEC's concerns. But despite this, there were ongoing problems of ownership of the process. This problem is discussed below.

There were other reasons to run an extensive new process of community awareness for the 2007 elections. LPV was new to most of the country and it was imperative that as many people as possible understood how to mark their ballot papers effectively under the new system.

In addition, the PNGEC itself did not have the resources available to reach into the remote areas of the country with electoral information. Educating the public in Papua New Guinea is a real challenge due to the inaccessible terrain and lack of road transport systems into much of the country, the numerous languages and cultural differences among target audiences, and the low levels of access to the media. This is compounded by low literacy, particularly among women and older people.

In the past, the commission had relied principally on the mass media and publication of written materials which were distributed through the provincial electoral offices. It had also run a LPV awareness campaign through the provincial election managers. The idea was that managers would work through district and local-level government officials to spread the word across the country. This process was not evaluated formally but its impact appears to have been mixed. In areas where there was a better-functioning local-level government system, such as Milne Bay and East New Britain provinces, the results were better. In areas where local- and district-level officials were closely aligned with candidates, the process did not work at all and was in fact used to reinforce corrupt voting practices in favour of preferred candidates. 
The awareness process through the local-level government system was linked to the roll enumeration. Officials were trained in LPV at the same time as they received training on how to enumerate the roll, and they were supposed to run awareness campaigns at the same time as gathering names for the new roll. It may be assumed, therefore, that where the roll enumeration did not work (most of the Highlands provinces and National Capital District, for example), neither did the electoral awareness. Feedback from election managers themselves was that the election awareness took a backseat to the roll. This was because of the high interest in manipulation of the roll and because people were desperate to get their names on the roll. Feedback from community members about the roll enumeration process also suggests that in many cases election officials did not go beyond the end of road to collect names; it can be assumed that very little awareness went beyond the end of the road either.

This is another reason that the civil society electoral awareness was considered important: we assumed that locally based members of community organizations would be better able to take the message back to their local areas.

We also assumed that community civil society workers would be able to use their local networks and languages to deliver election messages. With the high level of illiteracy, we hoped that CSOs would pass on messages verbally rather than use primarily written materials. Use of the media and development of print materials is also expensive; funding local people was much more cost-effective.

Finally, CSOs and non-government organizations wanted to be involved. We did not formally advertise the grants through the Electoral Support Program but we were inundated with applications just the same. There was a huge demand from CSOs across the country to be involved in running electoral awareness programs. There seemed to be the beginnings of a nationwide movement; local groups wanted to educate people about the basics of a democratic system and the role of good leaders, as well as how to fill in a ballot paper correctly. It was opportune that the Electoral Support Program could nurture some of this energy to grow a demand for free and fair elections.

\section{The campaign}

\section{Administration}

First, we set up the Communications Advisory Group (CAG), chaired by the director of the Information and Community Awareness Division. Some key CSOs were represented, including Caritas, Transparency International (TI) and Papua Hahine. Government departments and community police were also represented, 
as was the Community Development Scheme, a large AusAID-funded program providing resources for community groups across the country. The media was represented through the National Broadcasting Corporation.

Initially the role of the CAG was to oversee civil society funding, but subsequently the group was given responsibility for overviewing the whole of the communications strategy. When this happened, the CAG still made ultimate decisions about who should receive funding but each reported under the three outcome areas of the PNGEC's communication strategy. The CAG became more a participative group than an administrative one. The idea was to enable the CAG to have a voice within the PNGEC on voter education as a whole.

Under the overall communication strategy, the PNGEC spent just over K588,000 on 13 launches of LPV awareness materials. A further K2.3 million was spent on awareness materials for radio, TV and newspapers. (After the election, there was still over K93,000 in outstanding claims from the media.) Under the Electoral Support Program K5.2 million was spent on funding CSOs and a further K1.5 million on media awareness and the development and production of awareness materials such as posters, pamphlets, and T-shirts.

Forty-five groups were funded to run electoral awareness; five were de-funded because of mismanagement. Incomplete records show that electoral awareness community teams contacted at least 750,000 people personally. About onethird of these were women. This represents an expenditure of K7.4 per person contacted.

The largest amount of money $(\mathrm{K} 785,125)$ was given to TI, which used this mainly to develop some excellent materials on governance which were used throughout the campaign by other CSOs and by the PNGEC itself. (In fact, due to the delay in production of official awareness materials, the PNGEC often had only the TI or Caritas materials for their electoral awareness launches in the regions.) The smallest amount $(\mathrm{K} 10,830)$ was given to Meri i Kirap Sapotim to fund electoral awareness for the Chuave by-election of 2006.

The Electoral Support Program funded over six million pieces of educational material or media events which carried the message to the public, at a cost of K1.03 per person nationally. Difficulty of access in the rural areas resulted in urban people having twice as much money spent on them. We tried to equalize this by ensuring that the majority of CSOs funded were in rural and remote areas or in high-risk areas such as Port Moresby and Lae.

Unfortunately, the PNGEC did not allocate funds to assess the effectiveness of the program funded through the commission itself, so much of this paper relies on information received from the evaluation of the Electoral Support Program component of electoral awareness. 
Within the program, all expressions of interest and applications were assessed against rigid criteria, which included:

- the capacity of groups to run the program

- the inclusion of cross cutting issues such as participation of women, and HIV/AIDS prevention

- the degree of election risk

- population - we tried to make the grants correspond to population numbers across the country (more people live in the Highlands so more money was spent there)

- the kind of program groups wanted to run (preference was given to face-toface, grassroots processes after a while, as we began to see that these were far more effective)

- the budget (was it overblown or did it look legitimate?)

- involvement of election managers in development of the activity application.

Later on in the program, once a number of groups had been funded, gaps were identified across the country, and proposed projects within those gap areas were given priority. Once the assessment of the hundreds of applications was complete, recommendations were presented to the CAG. There was lively debate within the group, which provided a forum for sensible and informed decisionmaking.

The capacity of groups was not taken into account in the first round of funding. Consequently, some of the first groups to receive funds needed major assistance to deliver their programs. Some rang the office five times a day for advice on anything from the content of their election awareness campaign to acquittal of funds. We could not sustain this level of contact, and in the end had to assess the capacity of groups to run their projects.

The program officer, Esmie Sinapa, had the job of running initial project training for each group. Once groups had been deemed successful by the CAG, she visited them on site to assess whether they were bona fide groups, and spent up to two days helping them draft activity plans and realistic budgets. We were not so much interested in saving money as in giving groups the right amount of money to run a viable activity. Budgets often changed once the activity plans had been written.

The program officer always alerted election managers to her travel plans and invited them to the meetings with the group, but they rarely accepted the opportunity. Some felt the process of selection bypassed them and that groups should be vetted by election managers first and selected within the province. Others disagreed with the whole funding program because they felt the money should have gone to them to run election awareness. There was a strong resistance 
to changing the way in which voter education had always been done; it was seen as the territory of public servants, even though very few public servants were interested in going beyond the end of the road to educate people. This kind of competition undermined the process throughout. Nevertheless, three or four election managers saw the funding as beneficial. They understood that working with CSOs could greatly extend the reach of community awareness and therefore alleviate their workload. They participated actively throughout the program and the CSOs in their regions benefited from their technical expertise in election matters.

Once groups had undergone the project management training, they had to attend our electoral awareness training.

\section{Everybody's Business: Awareness training for civil society}

I developed a three-day course, entitled Everybody's Business. This became necessary because every group we funded, except TI, Caritas and Meri $i$ Kirap Sapotim (the only three groups in the 45 who understood elections at all) expected us to train them before they went off to run their program. The program had not foreseen this need.

The first training I ran was in the first two weeks of my arrival in Papua New Guinea. I went with my counterpart and another electoral official to observe them training district officials in Milne Bay for the roll enumeration and electoral awareness roll-out. The Electoral Support Program had funded the Milne Bay Theatre Troop to develop and perform a play on electoral issues primarily to educate remote communities.

My only preparation was reading the material about LPV provided by the PNGEC for district officials, and reviewing potential training material TI had begun to develop. In this material, TI described a 'paperless' voting process in which the audience nominate candidates, who make 'policy speeches', and then the audience lines up behind their preferred candidate; a count is done; if no candidate reaches 50 percent plus one of the votes, the candidate with the smallest number of supporters is knocked out and the people standing behind that candidate go and join the line behind their second preference, and so on.

We met the theatre troop in the village, where the team leader attempted to explain the counting procedure on a whiteboard. He was met with blank stares; no one could understand the process. We conferred and agreed to run the paperless voting process. It was a great success, and gave me my first hint 
that participation in voting procedures was the best way of understanding how things worked. We returned two days later to view the performance; it was shaky but had potential.

From this experience, I developed a one-day course on LPV and trialled it with the Salvation Army. The course covered what the old first-past-the-post system was, how it differed from the new one, how the new LPV system worked, and why the roll was so important. Each exercise was participatory and involved lots of role playing. People enjoyed the course but wanted more background information: Why did Papua New Guinea have a democratic system? What exactly was this, and what could be done about encouraging people to vote for leaders who were not corrupt?

I developed a second day of additional material about what the system meant and how government works in Papua New Guinea, including what the role of elected representatives was and what kind of person made a good leader. The additional day included quiz shows and other ways of getting people moving around, and was enjoyed by all. I was indebted to Meri i Kirap Sapotim and TI for the use of some of their good governance training material in this second day of training.

We trialled the revised training with Central Besena Mauri Ihatabuna and then the Young Women's Christian Association. Women's issues were mainstreamed into each exercise. But I also wanted to include HIV/AIDS issues. By this time I had been in the country for several months, and concerns about elections being an enabling mechanism for the spread of HIV infection had become clear. There would be more than 36,000 male election officials with money moving around the country during elections. Men, mobility and money are three key factors in the spread of AIDS. As well, some of the cultural conventions that had grown up around campaigning in the Highlands and in Port Moresby and Lae were a worry - in particular, 'campaign houses', meeting places built for candidates to gather with supporters. Risky sexual behaviour was rumoured to occur in these venues, which were an inherent element of the party atmosphere of elections in some places (see, for example, 12).

I therefore wanted to include something specific about women and elections and about HIV and elections. Another day was added to cover these areas. The women's section took the form of story about a day in the life of a woman trying to vote for the person she wanted to vote for, rather than the person for whom her husband said she should vote. The HIV section borrowed heavily from the National AIDS Council Secretariat training manuals about the spread of AIDS. 
I also included three surveys in our training manual (see below) to assess the level of understanding of LPV and electoral roll-related behaviour; to assess how the training had affected people's understanding of the system, and to assess the level of interest in changing some of their existing behaviour.

Finally, I added a code of conduct (based on one given to me by the Community Development Scheme) that stipulated that all CSOs should refrain from using their project to support particular candidates, should treat everyone (men and women) with respect, and should avoid risking transmission of HIV. The teams themselves became a risk of spreading the infection. This code of conduct became an important management tool; we came back to it several times during the program to enforce political neutrality. It was carefully explained during training, and everyone signed it and kept a copy.

I trialled the training course successfully with about five other groups. No one understood LPV before the course but afterwards all did. All sorts of electoral roll-related behaviour were uncovered, which at least some people were keen to correct. Almost all felt they had enough technical knowledge of elections, along with some practical methods of imparting that knowledge through using the exercises they went through in the training.

We prepared a training manual, entitled The Electoral System: Everybody's Business, which included training exercises and other material required by trainers, and also the code of conduct. The manual was universally liked and used while people were out in the field. In hindsight, it should have been waterproof, with laminated posters and mock ballot papers, so that people did not have to photocopy new material every time they went bush. A daypack would also have made it easier for people take the package with them with a small portable whiteboard. Another day could have been added to cover how to plan and run an election awareness project and how to manage the project cycle; many people struggled with these management issues.

Once the program was complete and the manual printed, it was appropriate to contract the training out to Papua New Guinean trainers, who could run the training in Tokpisin rather than English.

Ideally, there would have been four training teams: one in each region. However, as with almost everything else about this program, we had to hit the ground running. There was a backlog of about 10 groups waiting for training before going out. ${ }^{2}$ A lengthy selection process was not possible. Instead, Meri i Kirap Sapotim was invited to submit a proposal to run the training (I had reviewed

2 After seeing the huge need for the training, we made it mandatory for groups to complete it before starting their project so we knew they had the technical expertise to give the public correct information. The training thus became a mechanism for quality control as well. 
the training material they had created for their members and had seen they had training skills. I also wanted to have a gender balance of trainers). This organization was set up by women and their supporters to help women wanting to run for election; it subsequently broadened into general election awareness for women and men across the Highlands. The group had competent, confident women trainers who understood elections and gender equity. I wanted them to bring this to the training and to show other women that elections truly were everybody's business. As most groups we funded were based in the Highlands, it also made sense to contract a local group from that region.

Although more than 3500 people were trained, we have evaluations from only 459. The others were trained by CSO members who attended our official training first. The evaluations showed that people had the skills they needed to run their projects after participating in the training.

When asked what three things worked best about the training, 98 people said 'the trainers'; 92 said something about the content (such as, 'the training was the best ever because it was just in time to equip us to cast our votes for the right people and in the long run, this will have a great impact on the lives of the people'); 87 people said the thing they liked best was learning how to train others. People particularly liked the mock election exercises (both with and without paper votes). Seventy people said they liked the training manual itself and the other information given to them.

The things they most liked learning about were LPV (299 responses), governance (151), HIV/AIDS (101), electoral processes like polling, the roll, etc. (100), democracy (97), vote counting (85), and women's issues (56).

Things people wanted were more role playing, longer training, and better training on HIV. The HIV/AIDS section should have been done by special HIV trainers; our trainers did not feel very comfortable running this section. Again, lack of time precluded coordination with provincial AIDS trainers.

\section{What happened?}

Much of this section draws on the evaluation we commissioned. 1071 people were consulted in the evaluation process, before elections, during elections and afterwards. There were also 10 site visits to five case study projects - five before the elections and five after. Case studies were chosen to represent a range of important parts of the awareness process: a national project that did grassroots awareness as well as development of poster awareness materials (Caritas); a provincial project which showed innovative partnerships (Chimbu community policing project, which linked with a range of CSOs to run awareness across 
the province); a foot patrol project in a high-risk area (by Ima Kelo, whose members walked across five of the electorates that failed in the 2002 election in the Southern Highlands Province, over a period of seven months); a women's project (Papua Hahine, based in the Southern Region, which also ran awareness for potential women candidates); and Morobe Theatre Troop, based in and around Lae and closely coordinated with the election manager's office in the province.

In addition, the evaluation team talked by phone with every project manager and ran a number of pre- and post-polling focus group discussions with teams running awareness. At the end of the evaluation, 62 people attended a workshop in Port Moresby to verify or challenge the findings. All election managers attended this workshop and were invited to focus group discussions throughout the evaluation process.

The team also sought feedback about materials developed by CSOs, from those who used them, as well as from other CSOs and the Electoral Commission.

A major literature review was done of documents about voter awareness in general (see Gari, Holm and Ferguson 2008). The reviewer, Suzette Holm, also read the reports submitted by CSOs at the end of each funding tranche to ascertain progress, collate numbers of people reached, and generally monitor progress.

The evaluation sought to answer two questions: Was funding CSOs to run election awareness efficient and effective? How did voter knowledge, attitudes and behaviour change as a result of civil society electoral awareness processes?

Of 45 groups funded, five were de-funded, due to either deliberate mismanagement of funds or breaking the code of conduct through obvious involvement with candidates. Election managers were particularly concerned about this last - which is interesting, as many brought their own very clear biases to the workplace. Involvement with candidates was often used by election managers to support the argument that CSOs should not be trusted and that funding should revert to the Electoral Commission.

In total, the time spent on electoral awareness by CSOs in the nine months preceding the election amounted to 230 months - almost 19 person years. Group reports showed that 750,000 people were contacted personally, though this is an underestimation as many groups neglected to collect such statistics regularly. About one-third of those contacted were women, demonstrating that public awareness processes were not equally accessible to women and men. The total cost of the process was K5.2 million. 
Over six million units of electoral awareness materials were developed, including T-shirts, matchboxes with voting messages, posters, media announcements, talkback radio shows, TV advertisements, and newspaper articles. A further K1.5 million was spent on this. Although this is an impressive number of media units, it was limited largely to urban areas. Few people in rural areas saw or heard any of this information. Posters and T-shirts used by CSOs when they went out in the field were the exception. The evaluation showed that the materials developed were of a high quality and people liked them, but they were not an effective method of voter awareness when used as a stand-alone method; to really be effective, they needed to be used as part of an educative dialogue.

A major problem in development of voter materials was the legislative changes to the format of the ballot paper. The materials that had been developed showed the ballot paper with 1,2 and 3 against candidates' pictures; suddenly, the ballot paper changed to having boxes in which people were required to write candidates numbers and/or names. As a result, most materials were not produced until after January 2007, although electoral awareness teams were in the field much earlier and needed materials showing the new format.

Important ingredients of success in voter awareness were participation, and the use of relationships. Small group discussions were more likely to increase voter awareness than large market gatherings. Large market gatherings were effective in spreading the word about LPV and the mechanics of elections, but more complicated information about governance was mostly lost in such settings.

The evaluation revealed that the Electoral Support Program itself lacked capacity to run the program smoothly. A major problem was that tranche payments were often late, leading to delays in CSO projects, and much angst. This lateness was a mix of insufficient staff and too much work, combined with delays in receiving funds from AusAID. Added to this was the fact that we seriously misjudged the ability of many groups to run basic projects. The first activities funded required a huge amount of support to keep them running. This led to the subsequent inclusion of existing capacity as one of the selection criteria for successful applicants. Pleas to the program team leader to increase staff levels brought no action. Full-time administrative support was needed to run such a grants program; instead, we had a series of ineffective accountants.

The Electoral Commission itself lacked capacity to recognize the value of the program and use it to their advantage. A number of power brokers within the commission saw the program as being in direct competition for funds. It ran against the culture of working only with public servants on election matters. Many provincial election managers resented the fact that final decisions about which activities should be funded came from the advisory committee, rather than themselves. The difficulty of turning over decision-making to election 
managers was that many would have used the program as a way of furthering their own connections with candidates. We could not be sure that final decisions would be fair and useful. Perhaps they felt the same.

If funding of the program were to be a long-term part of the commission's work, we would have had to facilitate a process that did not necessarily involve the community's participation. As it was, the program was a short-term donor-funded initiative which had a much wider focus than the PNGEC's usual work. It was about support beyond government to grow a demand in the community for free and fair elections. This was a legitimate aim in itself, yet poorly placed within the commission, whose mandate was not that broad. Many of the PNGEC's staff did not understand the concept of good governance, or what democracy was about. They saw their role as running an election-churning people through polling stations and getting all the ballot papers collected and counted. This is the main reason the evaluation recommended that CSO awareness should continue, but that it should sit within an independent body. A conflict between the objectives of voter education and those of the commission was a sore point throughout the program and risked any beneficial outcome. Some powerful elements within the commission denigrated the work of the program.

One of the advantages of the program was that, for the first time, the public had a way of raising their concerns directly with the commission. CSOs regularly fed information back to the PNGEC about what they saw in the field: where the roll was particularly bad; where the trouble spots were; the performance of election officials in the field; what women were saying about wanting to be included. However, very little of this information was used within electoral operations, because of the resistance towards and distrust of CSOs within the commission.

The design of the Electoral Support Program exacerbated these problems, as advisers were slotted into pigeon holes across the commission rather than being able to relate directly across the commission's staff. I could only pass on information from the community to my counterpart or other advisers, and it depended on their levels of interest and power as to whether they effectively raised the issues with others. My counterpart, the director of the Information and Community Awareness Division, had her own interests to protect within the commission and this at times inhibited what she could pursue. On the one hand, she was excited about the work and the success of the Communication Strategy; but on the other, she shared some of the misgivings of other PNGEC staff about broadening electoral matters beyond the public service. Changing the way things were done was a challenge, and required unceasing leadership on her part.

The evaluation also revealed a severe lack of capacity within CSOs at various levels. I remember on my first trip to work with the Milne Bay Theatre Troop 
realizing suddenly that the leader of the troop could not add up basic figures. I tried to teach him using the receipts he had already kept but became acutely aware that our project management expectations were far too ambitious for someone in his position, yet he would still need to acquit tens of thousands of kina in grant money. To his credit, he did, but it was a very trying process for him and for us in the Electoral Strengthening Project (ESP). Lack of skill in running projects was an almost universal problem, except for the larger, more experienced CSOs. Many groups did not understand what we expected of them, even after several days of explaining and training.

As well, many CSOs were difficult to manage. During funding rounds, when groups were waiting to hear whether their applications had been successful, we had to employ a security guard to stay inside the office with us. Many groups used standover tactics in an effort to get their way if they had been unsuccessful. We worried about our safety during these times.

We also needed to be constantly on the lookout for financial 'sleights of hand'. In most cases this was due more to lack of skill than to corrupt behaviour. In some cases, though, groups had to be investigated and de-funded. The code of conduct was invoked several times when we heard that members of CSOs we had funded were going to run for election. We did not want to stop them running, we just did not want our project used in campaigning.

Groups used a range of strategies: some worked in schools to educate students; some went on foot patrols across their regions, or hired boats to get to remote locations, some made up plays or used singsings. Almost all ran mock elections in market places or other public spots. Some even ran sessions while travelling on public motor vehicles.

People risked their lives doing this work. There were stories of flash floods and people being swept downstream from their campsite by the river. I visited some teams who were using vehicles that were barely holding together, slithering around muddy mountain roads. On one occasion, in the Chimbu police project, when a massive spring snapped in the utility vehicle a member of the team walked back to town and got a replacement, weighing over 80 kilograms, which he carried on his back for five kilometres. The Chimbu police team leader got a leech in his eye and had to put up with this for two days on patrol. People got stranded for long periods of time in remote locations due to mechanical problems with small planes or the weather. They had to create their own bridges out of bits of corrugated iron, or trees they chopped down. They endured hostility from villages who felt angry about lack of representation of their needs in parliament and, not having access to their local member, hurled abuse at awareness teams. 
Very few people on foot patrols had decent equipment. They had not thought to ask for boots, raincoats, torches, etc. They expected so little. Once we realized this was the case, we remedied it, but many people took their messages to the people on bare feet, enduring lack of food and having slept in the open for many nights.

If anything bad had befallen anyone on the program, apart from the horror of the actual event, there could have been a slew of compensation claims, not just against the Electoral Support Program but also against the commission, and others in the awareness teams. One of the recommendations of the evaluation was therefore that before any similar program is undertaken, insurance needs to be sorted out.

\section{Growing a demand for better governance}

As argued earlier, personal interaction was the most effective ingredient of successful voter education. The awareness changed voter behaviour; it helped voters know how to vote, for one thing, but, more importantly, some people on the awareness teams changed their voting behaviour from culturally acceptable but negative use of the system (accepting bribes from candidates, getting their names on the roll as many times as possible, and so on) to commitment to free and fair elections.

For example, the subject of one of the case studies in the evaluation was Ima Kelo, a local CSO based at Lake Kopiago, which worked in partnership with The Australian National University. It was funded to run grassroots election awareness across the five open electorates which produced failed elections in the Southern Highlands in 2002. The elections failed in 2002 due to massive fraud and use of violence. Despite the new roll there were still major problems: the rolls were grossly inflated yet many people were still not listed. This group reached out to over 100,000 people in their project. They walked, carrying portable whiteboards to run mock elections. They ran awareness sessions from public motor vehicles for workers along the side of the road; in fact, they ran sessions wherever they could get a group together. They calculated they had covered at least 50 percent of the voters in the province. Ima Kelo partnered with other local CSOs across the region. Core members were trained in Lake Kopiago by our trainers who stayed on to support the process. Men and women worked together doing this work.

In the past, Ima Kelo members had been actively involved in typical electoral fraud and corruption. One team member had been the first to use guns in elections in his electorate. However, during the electoral awareness process people in this team convinced voters living in South Koroba to clean their roll. 
Members of the awareness team sat with the community over a period of days and went through every name on the roll, verifying or filling in the necessary paperwork to alter the entries. They managed to reduce the numbers on the roll from 19,000 to 10,000 , though they received threats from the supporters of one candidate who was disadvantaged by the corrections.

Running daily awareness sessions in difficult conditions over eight months somehow changed them. Perhaps it was because repeating the messages raised their awareness about the need for free and fair elections. Maybe the sacrifices involved in months of walking the province made them determined to see some changes. The team suffered in the process: they were away from their families for months at a time and on their return many were physically exhausted. Their efforts illustrate the massive commitment ordinary people in Papua New Guinea made to run the education process.

In Chimbu, the group running the community policing CSO partnership showed similar commitment and results. This project was coordinated by a local inspector of police (see chapter 7). His job was head of prosecutions, not community policing, but most criminal activity in 2007 was going to be associated with elections, so it was best to try and prevent such offences before they occurred. The Electoral Support Program had funded a range of CSOs in Chimbu: Meri i Kirap Sapotim, Community Development Scheme Core Group, Tribal Arts, and the national projects, Young Women's Christian Association and Caritas. The inspector brought all groups together and worked out how to cover the province with a broken-down police vehicle and on foot. Teams worked with local leaders to arrange times to run awareness. They set up mock polling stations and showed how elections should be run. They worked with HIV trainers to give information about the risks of catching the disease through electionrelated activities. They also conducted role plays demonstrating acceptable and unacceptable behaviour. They spoke to over 60,000 people across the province, sometimes in areas where local communities had rarely seen government officials. Women went on foot patrols too and participated alongside men. They were able to do this partly because they had police protection, but also because the team leader allocated special allowances (called 'family allowances') which were intended as a sweetener for their men staying at home - the whole family benefited directly if the women participated. As with Ima Kelo, some members of the team took it on their shoulders to try and clean their local rolls by taking copies to local meetings and urging people to check their names.

After the election, some members of this team continued community policing, unpaid. One extraordinary woman, Pauline Kenna, a lawyer, using the contacts she had made with the police, went back to her electorate to consult with her people about what they saw as their key problems. People responded that the use of marijuana and homemade liquor were a major source of violence in the 
region. She and police she could trust set up a community policing project; 250 people have now attended human rights training run by Pauline and the police and are working with the community to uproot marijuana plants and bring about more lasting peace.

The team leader of this project also made valuable links with communities that he was able to use beneficially after the election. He established good connections with local leaders and knew where trouble was likely to occur. When tribal fights broke out due to disgruntled losing candidates, he went in with police and was able to broker peace, probably saving many lives.

This project also brought significant wider changes. Women involved in electoral awareness were able to lobby the Electoral Commission to run separate polling booths for women as a way of reducing intimidation of women voters. This demand came from women voters across the Highlands. Due to the confidence of the women involved in electoral awareness, the PNGEC finally heard their demands and agreed to give the idea a go. ${ }^{3}$

As well, in Chimbu there was a significant decrease in the use of campaign houses. In one electorate there were only three, and these were used by our awareness teams warning people of the dangers of catching HIV/AIDS in such venues. The use of campaign houses went down in every Highlands province except Enga, where there was a gap in CSO electoral awareness.

Also noticeable in Chimbu was that a number of candidates used some of the good governance slogans from the awareness teams in their own campaigning. Indeed, the governor and two open candidates were elected without evidence of money politics - an outcome attributed to the layered approach to electoral awareness and a critical mass of people beginning to absorb its message. One of the key CSO people was put in charge of counting for the Chimbu regional seat, and he and others from the awareness campaign refused several large bribes (in his case K100,000) from candidates to rig the counting. He quoted the governance messages from the campaign as the key reason that he would not accept the bribe.

Another project we funded, the Lower Unggai Community Development Foundation, provided a different outcome. This project was run by a capable woman, Sallyn Lomutopa. She organized and trained a number of local people using the ESP training process, then ran awareness across the region. In the course of this awareness, she was approached many times by residents asking

3 Unfortunately, it was not particularly successful due to poor organization on the part of the PNGEC (for example, not providing enough polling booths to allow for it), or because it was not enforced by polling officials. Many women in remote areas are illiterate and candidate supporters were still able to force themselves into polling places and convince women voters to write down what they wanted them to. 
her to run in the election. After the project had finished, she decided she would do so. Without involvement in the awareness, she felt she would not have had either the technical skills or the confidence to try, especially in her Highlands electorate where few women would attempt to run.

Involvement in the process also changed those electoral managers willing to work with CSO members. The electoral manager in Chimbu told an Electoral Commission forum to discuss the local-level government elections in 2008 that elections had run smoothly because of the voter education process in 2007. Communities knew what to expect and were more willing to cooperate with the PNGEC than in previous elections. He was able to find people across the communities who understood elections and could run polling stations.

It was not all good news though. CSOs were often male-dominated and fewer women attended electoral awareness sessions than men. Electoral awareness did not change the situation for many women voters, who continued to have their votes controlled by male clan members. It also did little to increase the vote for women candidates; only one woman was elected to parliament and she was a sitting member who had to fight for her seat in 2007. At ESP, we tried to ensure that CSOs reached out to women voters by not paying the next tranche of funding unless groups could demonstrate they had educated women. This had some impact, but, as noted above, only one-third of those contacted in the education campaign were women.

Some CSOs exhausted themselves in the process. Meri i Kirap Sapotim fell apart during the course of the awareness. We funded them to run train-the-trainer sessions, developing groups of interested people across the Highlands. They completed this complicated task very well and emerged as a group with a great deal of capacity. Therefore, we asked them to run our training for us. Again, they did this well, although at one stage I had to insist they stick to our training manual rather than reverting to theirs. Running the training gave them a great sense of ownership over it, which was good but began to blur the boundaries between our responsibilities at ESP and theirs as consultants running our training course. We topped up their funding to continue regional awareness across the Highlands but their capacity became overstretched and the organization started to implode from stress. Personal rifts grew stronger and became destructive, leading to the eventual collapse of the organization - a classic case of donors overusing capacity within CSOs. We needed the organization as they knew what they were doing and kept delivering, and they wanted our funds to make them sustainable. Sadly, this combination of needs became damaging. I do not think that our funding was responsible for their demise, but it probably exacerbated existing tensions. 


\section{Conclusion}

The successful mix in voter education seems to have been a critical mass of awareness, as in Chimbu where a layered approach worked well, together with a substantial coverage of the province so people heard the messages over and over again in different ways. Involvement of Electoral Commission officials was important. In Morobe, the election manager's staff coordinated and funded the Morobe Theatre Troop, so that troop members had official support during their work rather than having to establish their legitimacy, as in some provinces like Gulf where election officials actually heckled the awareness team and tried to undermine their work publicly.

There were also unintended consequences of the awareness. Some longer-term partnerships developed between unlikely groups that have continued beyond the project, such as the police and CSOs in Chimbu. One outcome of this has been the establishment of a women and children's desk within the police station to handle domestic violence complaints.

Running awareness projects increased CSO capacity in project management, which should improve their ability to access further funding and make their organizations more sustainable. The awareness exercise also left a pool of trained people around the country who understand how polling stations should be run and how counting should be done; this provides an excellent resource for the PNGEC in the future. ${ }^{4}$

The process also mobilized hundreds of ordinary citizens to observe the election process. Their desire was twofold: they wanted to check whether their awareness had worked and they felt a responsibility to witness elections as concerned citizens, believing that their presence might go some way towards encouraging better voting behaviour. Being involved in running voter education nurtured a demand for better governance and free and fair elections across the country. This was perhaps the most important outcome of the process: many of those who participated in running electoral awareness changed their own behaviour and wanted to help change others. Without this growing desire, elections in Papua New Guinea cannot be run democratically.

The forces behind some of the fraudulent election behaviour are strong, especially the win-at-all-costs mentality of candidates and supporters. Poverty affects the running of elections: for many people, election time is the only time they can get cash, mostly through payments from candidates. Lack of education

4 Before the 2007 national election, over 36,000 people were recruited to staff polling stations. The commission tried to provide training for all these people but observation suggested that training was often substandard or non-existent. It is an almost impossible task to train such a vast number of people in the few months before elections. 
is another factor in poor behaviour during elections. Many people simply do not know why elections are run. They have not been taught what elections mean, what the role of parliament is, or indeed what their local members should be expected to do for them. In remote areas, the level of illiteracy is very high. In highly populated remote areas, our groups estimated that nearly 90 percent of voters were illiterate, especially women and older people. This provides a huge opportunity for supporters to manipulate people's votes: if you cannot read your ballot paper, you have to rely on others helping you; at each polling station there are swarms of candidate supporters ready to step up and fill in peoples' ballot papers for them. Illiteracy affects more women than men and contributes to the lack of power that women have in public affairs, including the election process. Women's votes are more likely to be co-opted and lack of literacy enables further abuse of power.

In the face of these entrenched societal problems, voter education which encourages a sense of community responsibility for free and fair elections is the key to positive change. We found that the election awareness training, combined with active participation in voter education, led to significant changes in the behaviour of some educators, and helped to create a widespread desire for good leaders.

It remains to be seen whether this movement will continue to grow and become more effective in changing electoral culture for the better. Such a development will require long-term funding and support and a commitment from government to listen to the wishes of the people and allow them to participate beyond filling in their ballot papers.

\section{References}

Ferguson, S., 2007. Everybody's Business! Awareness Training for Civil Society. Port Moresby: Electoral Support Program.

Gari, S., with Holm, S. and Ferguson, S., 2008. Civil Society Organisation Engagement in Electoral Awareness. Port Moresby: Electoral Support Program.

Ladley, A. and Williams, J., 2007. Electoral Education in PNG: A Survey of Existing Literature and Reports. Wellington, New Zealand: School of Government, Victoria University of Wellington.

Papua New Guinea Electoral Commission, 2006. Election News! Election Sivarai! Eleksen Toksave! Everybody's Business. Unpublished, Port Moresby.

Vagi, M., 2007. Report on the Information and Community Awareness Division. Unpublished, Port Moresby. 